DOI 10.26886/2414-634X.5(41)2020.10

UDC 35.073.515.3

SUSPENSIVE CIVIL REMEDIES FOR THE RIGHTS TO MEANS OF INDIVIDUALIZATION FROM UNFAIR COMPETITION: CIVIL-

\title{
LAW RATIONALE
}

\section{A. Pekar, Applicant at the Research}

https://orcid.org/0000-0002-8942-8024

e-mail: letter@i.kiev.ua

Institute of Intellectual Property of the National Academy of Science of Ukraine, Kyiv Ukraine

The article presents an analysis of the concept and methods of civil protection of rights to the means of individualization. The study provided grounds to identify common features of liability and protection measures: aimed at their impact on the offender; aim to protect the rights and interests of the victim; can be implemented both voluntarily and compulsorily; directly enshrined in law; have a retrospective character; can be used alone or in combination. Distinctive features are also available. The following criteria are defined: the first criterion is the presence of non-equivalent property deprivations in civil liability; the second criterion: invariability of protection measures and variability of liability measures; the third criterion is the temporal (temporal) criterion; the fourth criterion for distinguishing between liability and protection measures are the forms of their implementation. Thus, the study provides grounds to identify common features of liability and protection measures: aimed at their impact on the offender; aimed at protecting the rights and interests of the victim. The study provided grounds to identify common features of liability and protection measures: aimed at their impact on the offender; aim to protect the rights and interests of the victim; can be implemented both voluntarily and compulsorily; directly 
enshrined in law; have a retrospective character; can be used alone or in combination. Distinctive features are also available. The following criteria are defined: the first criterion is the presence of non-equivalent property deprivation in civil liability; the second criterion: invariability of protection measures and variability of liability measures; the third criterion is the temporal (temporal) criterion; the fourth criterion for distinguishing between liability and protection measures are the forms of their implementation. Thus, the study provides grounds to identify common features of liability and protection measures: aimed at their impact on the offender; aimed at protecting the rights and interests of the victim.

Key words: civil - legal protection of rights; means of individualization; intellectual property; unfair competition; measures of responsibility and protection.

здобувач Науково-дослідного інституту інтелектуальної власності, Пекар А. О., Припиняючі способи цивільно - правового захисту прав на засоби індивідуалізації від недобросовісної конкуренції: цивільно-правове обгрунтування / Національна академія правових наук України, м. Київ, Україна

У статті представлено аналіз поняття і способи цивільно правового захисту прав на засоби індивідуалізації. Проведене дослідження дало підстави виділити спільні риси заходів відповідальності і заходів захисту: спрямовані за своїм впливом на правопорушника; мають на меті захист прав та інтересів потерпілого; можуть бути реалізовані як в добровільному порядку, так і примусовому; прямо закріплені в законодавстві; мають ретроспективний характер; можуть використовуватися як поодинці, так і у сукупності. Відмінні риси також наявні. Визначено наступні критерії: першим критерієм $є$ наявність при цивільноправовій відповідальності позаеквівалентних майнових позбавлень; 
другий критерій: незмінюваність заходів захисту $і$ змінюваність заходів відповідальності; третій критерієм $\epsilon$ часовий (темпоральний) критерій; четвертим критерієм для розмежування заходів відповідальності $і$ заходів захисту $\epsilon$ форми їх реалізації. Отже, проведене дослідження дає підстави виділити спільні риси заходів відповідальності і заходів захисту: спрямовані за своїм впливом на правопорушника; мають на меті захист прав та інтересів потерпілого.

Ключові слова: цивільно - правовий захист прав; засоби індивідуалізації; інтелектуальна власніть; недобросовісна конкуренція; заходи відповідальності і захисту.

Вступ. Розвиток світової економіки та міжнародної торгівлі в умовах постійно зростаючої конкуренції, поява нових технологій і глобалізація сприяє тому, що спеціальні позначення, які індивідуалізують певного виробника та результати його діяльності набувають все більшого значення і їх роль зростає.

Правовий режим та сутність засобів індивідуалізації у межах наукового дослідження та у законодавстві $€$ не збалансованим. Вже протягом тривалого часу використання окремих розрізняльних позначень $€$ предметом нормативного впорядкування та наукового дослідження. Негативним, на нашу думку, $є$ те, що для правової охорони комерційного найменування не має спеціального законодавства. Для того щоб визначити його правову охорону потрібно дослідити окремі положення ЦК України, ГК України, Закон України «Про охорону прав на знаки для товарів і послуг», Закон України «Про захист від недобросовісної конкуренції», інші законодавчі акти та практику суду. Застосування судової практики при вирішенні спорів 3 
охорони прав на комерційне найменування говорить про те, що існує низка питань, вирішення яких законодавством не передбачено.

На даний час, ефеекивність цивільно-правового захисту залежить від виду вимоги, що ставляться до порушника. Визначаючи вид вимоги, особа може зіткнутися з проблемою, коли одні й ті ж самі протиправні дії породжують виникнення різних цивільно-правових вимог до одного й того ж суб'єкта. Задоволення хоча б однієї з них призводить до припинення іншої. Отже, з'являється декілька шляхів досягнення кінцевої мети - відновлення порушеного права або захисту інтересу. Таке явище на теоретичному рівні традиційно іменується «конкуренцією позовів» («конкуренцією вимог»).

Дослідженням даного питання займались такі вітчизняні науковці: Г. О. Андрощук, Ю. Л. Бошицький, Т. С. Демченко, О. Ф. Дорошенко, О. Ю. Кашинцева, А. О. Кодинець, В. М. Крижна, Н. А. Іваницька, Н. М. Мироненко, О. П. Орлюк, О. А. Підопригора, О. О. Підопригора та інші.

Мета статті - аналіз припиняючі способи цивільно - правового захисту прав на засоби індивідуалізації від недобросовісної конкуренції.

Аналіз останніх досліджень і публікацій. Умови надання правової охорони торговельній марці, комерційному найменуванню, географічному зазначенню передбачені низкою нормативно-правових документів, серед них Цивільний кодекс України, Господарський кодекс України та інші нормативно-правові акти.

Для регулювання реєстрації, правової охорони торговельної марки та географічного зазначення існують спеціальні закони: Закон України «Про охорону прав на знаки для товарів і послуг» 1993 р., Закон України «Про правову охорону географічних зазначень» 2019 р. Однак, і вони потребують вдосконалення, для того, щоб відповідати сьогоднішнім потребам захисту прав на засоби індивідуалізації 
учасників цивільного обігу, товарів і послуг та відповідати стандартам передбаченими міжнародно-правовими документами та законодавству $\epsilon C$.

За визначенням науковців, нормативні положення щодо регулювання інтелектуальної власності мають сприяти ефрективнішому руху у процесі визнання України в Європейському Союзі [10, с. 119]

Тому, ми вважаємо за потрібне врегулювання термінологічної різноманітності засобів індивідуалізації учасників цивільного обігу, товарів і послуг. Зокрема, ст. 420 ЦК України передбачає, що до об'єктів інтелектуальної власності належать торговельні марки, комерційні найменування та географічні зазначення.

16.08.2020 набув чинності Закон України № 815-IX від 21.07.2020 р. «Про внесення змін до деяких законодавчих актів України щодо посилення охорони і захисту прав на торговельні марки і промислові зразки та боротьби з патентними зловживаннями» відповідно до якого дефініцію «знак» як позначення, за яким товари і послуги одних осіб відрізняються від товарів і послуг інших осіб, замінено на термін «торговельна марка» таким чином було гармонізовано визначення цього терміну в главі 44 ст. 492-500 ЦК України, главі 16, ст. 157, 158 ГК України та Законі України «Про охорону прав на знаки для товарів і послуг» від 15 грудня 1993 року.

Стосовно комерційного найменування, то законодавство оперує, знову ж таки, кількома позначеннями - «комерційне найменування», «фірмове найменування», «комерційне (фрірмове) найменування». Щодо географічного зазначення, то Закон України «Про охорону прав на зазначення походження товарів» під правом інтелектуальної власності на зазначення походження товару, розуміє просте зазначення походження товару і кваліфріковане зазначення походження товару, яке включає назву місця походження товару і географрічне 
зазначення походження товару, а ЦК України передбачає право інтелектуальної власності на географрічне зазначення. Це пов'язано 3 тим, що в ЦК України застосовується більш широке поняття. Однак, на нашу думку, ЦК України повинно більш детально врегулювати зазначене питання. Закон України «Про правову охорону географічних зазначень» 2019 р Правовий режим такого засобу індивідуалізації як доменне ім'я, поки що ще, взагалі, не отримав законодавчого закріплення. Існують різні думки з приводу того чи є доменне ім'я засобом індивідуалізації чи ні, однак ми вважаємо за потрібне, врегулювати правову охорону даного об'єкту.

Адже, слід враховувати, що доменне ім'я, в певних випадках, може трансформуватися в позначення, що виконує функції торговельної марки, формально до неї не відносячись, і в такій ситуації в рамках конкретного спірного правовідношення, доменне ім'я можна віднести до такого об'єкта інтелектуальної власності, як торговельна марка.

Щодо умов надання правової охорони, то в даному випадку теж виникає багато питань. По-перше, щодо прав попереднього користувача на торговельну марку. ЦК України не передбачає: можливість захисту попереднім користувачам торговельної марки від неправомірного використання третіми особами, умови набуття права попереднього користувача у випадку, коли торгівельна марка буде визнана добре відомою, оцінних критеріїв для набуття права попереднього користувача - законодавством встановлено лише загальні засади. На нашу думку, така недосконалість $€$ значним недоліком і потребує врегулювання. По-друге, для захисту прав на комерційне найменування велике значення має питання його структури. Питання визначення складу комерційного найменування віднесено до компетенції суду та має вирішуватись ним відповідно до 
чинного законодавства і на підставі наявних у справі доказів. Однак, стає не зрозумілим на підставі якого закону та на підставі яких доказів, якщо не існує спеціального закону щодо комерційного найменування.

По-третє, у 2019 році набув чинності Закон України «Про правову охорону географрічних зазначень», до цього часу діяв Закон України «Про охорону прав на зазначення походження товару», створено відповідний державний реєстр, однак варто зауважити, що за час, протягом якого створили національну систему з охорони географрічних зазначень, кількість таких зареєстрованих позначень $є$ незначною.

Відповідно до даних комітету з питань економічного розвитку, в Україні станом на 1 червня 2019 р. зареєстровано 3115 географічних зазначень (кваліфікованих зазначень походження товарів). Більшість із цих ГЗ належать європейським виробникам і охороняються на території України на виконання Угоди про асоціацію з ЄС. Згідно національної процедури в Україні зареєстровано 42 кваліфікованих зазначень походження товарів (КЗПТ) та видано лише 34 свідоцтва на право використання зареєстрованих КЗПТ. Протягом 2014-2018 років подавалося 3 - 4 заявки на реєстрацію КЗПТ у рік. Тобто в Україні зареєстровано лише 14 КЗПТ стосовно українських виробників. При цьому 6 з них («Сонячна долина», «Новий світ», «Золота балка», «Балаклава», «Меганом» та «Магарач») зареєстровані стосовно виробників десертних марочних вин, вин, вин ігристих, що розташовані на території AP Крим. У зв'язку з анексію АР Крим такі КЗПТ не можуть використовуватись українськими виробниками.

У сучасному світі питання уніфікації правового регулювання захисту засобів індивідуалізації мають першорядне значення в контексті стабільного ефективного розвитку виробничо-торгового потенціалу як окремих держав, так і їх об'єднань в рамках універсальних та регіональних міжнародних організацій. Проблеми 
охорони результатів інтелектуальної діяльності, що виражаються в тих чи інших об'єктах промислової власності та прирівняних до них в контексті термінології українського законодавства засобів індивідуалізації, $є$ предметом обговорення науковців різних держав 3 давніх часів [1, с. 24].

3 метою залучення споживачів, підприємці використовують численні засоби індивідуалізації, останні набувають велике економічне значення. Засоби індивідуалізації визначають взаємозв'язок між виробниками і споживачами продукції i iнформують покупців про конкретного виробника, який маркірує продукцію, її якості, основні характеристики та місце походження. Саме тому, необхідно досліджувати внутрішню структуру цивільно-правового захисту інтелектуальної власності як правового явища. Кращим способом вирішення цього завдання $€$ побудова науково-гносеологічної моделі механізму ії здійснення та аналіз складових елементів даного механізму [10, с. 120].

При цьому ми пропонуємо авторське розуміння механізму цивільно-правового захисту інтелектуальної власності, під яким розуміємо певне поєднання елементів, що складають його структуру і дають в кінцевому рахунку уповноваженій особі в разі порушення належних йому прав інтелектуальної власності реальну можливість вдатися до тих чи інших способів захисту.

Як вказується в літературі, реалізація права на захист завжди здійснюється в певному порядку, використання якого рівнозначно застосуванню належної форми, засобів і способів захисту.

Відповідно, на основі норм українського законодавства прийнято виділяти юрисдикційну форму захисту прав інтелектуальної власності, пов'язану $з$ діяльністю уповноважених органів. Щодо захисту порушених чи оскаржених прав, і неюрисдикційну форму захисту - 
самостійно здійснювані дії громадян і організацій щодо захисту своїх прав і охоронюваних законом інтересів (які, природно, треба відмежовувати від самоврядних дій) [2, с. 37].

Дана точка зору підтверджується положеннями, виробленими наукою цивільного процесуального права і з якого випливає, що спосіб захисту права - категорія матеріального права, в той час, як форма захисту права - категорія процесуального характеру, під якою слід розуміти діяльність компетентних органів, що має свою законодавчу регламентацію і спрямована на захист прав за допомогою властивих їй методів, які залежать від правової природи відповідного юрисдикційного органу. Такими методами можна вважати визначення даних про факти, використання щодо таких даних відповідних правових норм, за допомогою чого визначається необхідних спосіб захисту прав, прийняття процесуального рішення і контроль за їх виконанням. Задля застосування конкретного способу захисту, що передбачений в законі необхідно використати декілька фрорм захисту щодо порушеного права $[7$, c. 5$]$.

Юрисдикційна фрорма захисту інтелектуальної власності здійснюється в першу чергу судовому порядку, який $€$ одним 3 найважливіших елементів цивільно-правового захисту будь-яких цивільних прав, в тому числі і прав інтелектуальної власності, а також в адміністративному порядку.

У діючих в даний час в Україні нормативно-правових актах, що регулюють питання інтелектуальної власності, вказані різні способи захисту прав на ті чи інші об'єкти інтелектуальної власності.

Численність матеріально-примусових заходів, передбачених цивільним законодавством України і застосовуваних при захисті інтелектуальної власності, а також їх неоднорідність по своїй природі роблять необхідним їх класифікацію. 
Найбільш поширеним і досить глибоко обґрунтованим в цивілістиці $€$ поділ способів захисту на заходи захисту та заходи відповідальності, які мають такі критерії як підстави застосування, соціальне спрямування, виконувані фрункції, принципи реалізації тощо. По відношенню до заходів відповідальності та заходів захисту в літературі з загальної теорії права також використовуються терміни «правововідновлювальні санкції» і «штрафні санкції» [3].

Продовжуючи аналіз зазначеної проблеми, звернемо увагу, що заходи відповідальності, як і заходи захисту мають спільні риси: спрямовані за своїм впливом на правопорушника; мають на меті захист прав та інтересів потерпілого; можуть бути реалізовані як в добровільному порядку, так і примусовому; прямо закріплені в законодавстві; мають ретроспективний характер; можуть використовуватися як поодинці, так і у сукупності.

Наведення спільних рис заходів відповідальності і заходів захисту наштовхує на думку щодо відмінних рис, які $є$ не менш істотними. Так, першим критерієм $€$ наявність при цивільно-правовій відповідальності позаеквівалентних майнових позбавлень [12, с. 80]. Використовуючи цей критерій, пропонується розмежовувати заходи захисту і заходи відповідальності за способами, які вони використовують. Так, до способів захисту слід відносити відновлення становища, що передувало правопорушенню; зупинення протиправних дій; визнання порушеного права. Такі заходи представляють собою один з способів захисту права [11, с. 288]

Другим критерієм для визначення відмінностей заходів відповідальності і заходів захисту, на нашу думку, слід вважати такий: незмінюваність заходів захисту і змінюваність заходів відповідальності. Так, порушене право може бути захищено тільки прямо визначеним способом захисту. Водночас, заходи відповідальності можуть бути 
застосовані на розсуд правомочних осіб або органів. Заходи відповідальності можуть бути замінені іншими заходами відповідальності, що неможливо для заходів захисту.

Третім критерієм слід визнати часовий (темпоральний) критерій. Інакше кажучи, мова йде про визначення процесуальних термінів, протягом яких застосовуються заходи захисту або заходи відповідальності. Так, особливістю заходів захисту $є$ те, що вони застосовуються в терміни, коли суб'єктивне ще існує, але воно було порушено. Неможливо застосувати заходи захисту якщо право зупинило своє існування. В свою чергу, заходи відповідальності можуть бути використані як для відновлення порушеного права, що вже припинило своє існування, так і для відновлення права, що продовжило своє існування незважаючи на порушення.

Четвертим критерієм для розмежування заходів відповідальності і заходів захисту слід вважати фрорми їх реалізації. Так, заходи відповідальності можуть реалізовуватися за допомогою грошової або натуральної форми. Способів захисту, які можуть реалізовуватися в грошовій формі не передбачено законодавством (за деякими винятками). Всі ці характеристики переломлюються через особливості інтелектуальної власності і проявляють себе при використанні на практиці конкретних способів захисту [4, с. 188]

Крім поділу способів захисту інтелектуальної власності на заходи захисту та заходи відповідальності, існує ще кілька корисних класифрікацій для проведення ґрунтовного дослідження.

Відновлювальні способи захисту інтелектуальної власності спрямовані на захист виключних прав в тому вигляді, якими вони були до порушення, в чистому вигляді, тобто повернення в статус кво право володільця. Припиняючі заходи захисту інтелектуальної власності - це, наприклад заборона діяльності, що створює загрозу заподіяння шкоди 
правовласника в майбутньому тощо. Такі заходи захисту можуть бути застосовані у разі, якщо характер правопорушення $є$ триваючим, що досить характерно для порушень прав інтелектуальної власності. Заходи захисту, спрямовані на визнання права (або фракту) - це одні 3 найбільш часто використовуваних в праві інтелектуальної власності, які спрямовані на визнання фракту володіння правом за правовласником [2, c. 45$]$.

Заходи відповідальності за таким критерієм як функціональна спрямованість розподіляються на компенсаційні, штрафні та конфріскаційні.

Компенсаційні заходи відповідальності мають свою особливість, яка проявляється в тому, що розмір компенсації визначається розміром завданих збитків потерпілому.

Ринкова економіка сприяла тому, що штрафні заходи відповідальності стали найбільш розповсюдженими. Розмір їх обчислюється, виходячи з суми боргу, терміну прострочення і величини неустойки (відсотків). Використання таких способів захисту інтелектуальної власності найбільш характерно при договірних правовідносинах правовласника з користувачем.

Конфріскаційні заходи відповідальності мають своєю особливістю те, що неможливо зменшити розмір відповідальності, а також те, що вони реалізуються в добровільному порядку [6, с. 225]

За методом встановлення способів захисту, які використовуються в області інтелектуальної власності, їх можна розділити на договірні і позадоговірні; а також виділити змішаний вид - комбіновані способи захисту.

Коротко розглянуті вище цивільно-правові способи захисту являють собою як би статику механізму захисту прав засобів індивідуалізації. Тим часом, особливості захисту виключних прав 
можна виявити тільки при паралельному розгляді цього правового феномена який триває в часі процесу.

Точкою відліку для аналізу такого процесу $\epsilon$ «нормальна» ситуація, коли права інтелектуальної власності ще не порушені, ще не оскаржені. Правовласник при реалізації своїх виключних прав на об'єкти інтелектуальної власності перебуває з необмеженим колом третіх осіб у правовідносинах, які можна охарактеризувати як абсолютні. Як вказується в літературі, в абсолютних правовідносинах уповноваженій особі протистоїть невизначене число зобов'язаних осіб. Має місце юридичний зв'язок між визначеним колом суб'єктів, що уповноважені на використання права, тобто правоволодільцями, із невизначеним колом зобов'язаних осіб [5]

Проведений аналіз дозволяє розкрити саме цивільно-правовий аспект порушень прав на засоби індивідуалізації та їх захисту. Природно, що порушення виключних прав може містити в собі склад адміністративного та кримінального правопорушення, що робить можливим застосування правового інструментарію відповідних галузей права [9].

Серед цивільно-правових способів захисту можна виділити ряд способів, спрямованих на припинення та запобігання порушенням виключних прав і недобросовісної конкуренції з їх використанням. У світлі сказаного, відзначимо, що припиняючі способи захисту спрямовані на припинення порушення виключних прав на засоби індивідуалізації та недобросовісної конкуренції з їх використанням, а також запобігання в майбутньому повторних порушень виключних прав і актів недобросовісної конкуренції шляхом застосування заходів відповідальності.

До них слід віднести такі: припинення дій, які спрямовані на порушення виключного права або створюють загрозу такого 
порушення; вилучення 3 обігу і знищення за рішенням суду устаткування, пристроїв і матеріалів, використовуваних або призначених для вчинення порушення виключних прав; повна або часткова заборона на використання фрірмового найменування або комерційного позначення; визнання такою, що не відповідає дійсності правової охорони торгової марки; припинення юридичної особи або діяльності індивідуального підприємця в разі неодноразового або грубого порушення виключних прав.

Припинення дій, що порушують право або створюють загрозу його порушення, $є$ універсальним способом захисту цивільних прав та реалізує, головним чином, превентивні і припиняючі функції, даний спосіб захисту має міжгалузевий характер і застосовується для попередження та припинення правопорушення не тільки в цивільному, але і в адміністративному праві. Так, обов'язкові для виконання розпорядження антимонопольного органу про припинення недобросовісної конкуренції, пов'язаної з незаконним використанням засобів індивідуалізації, спрямовані як на захист конкуренції, так і на захист виключних прав правовласника - господарюючого суб'єкта. Припинення недобросовісної конкуренції в даному випадку передбачає припинення порушення виключних прав, тому правовласник може скористатися як правом на захист від недобросовісної конкуренції, так і правом на захист виключного права, вибравши відповідно адміністративний або судовий порядок захисту.

Припинення дій, які спрямовані на порушення виключного права на засіб індивідуалізації, передбачає заборону діяльності, пов'язаної $з$ використанням засобу індивідуалізації без згоди правовласника. Правовласник має право заявити вимогу про припинення дій, які порушують або можуть порушити його суб'єктивне право до особи, дії 
якої порушують або можуть його порушити. При цьому таке припинення здійснюється незалежно від вини порушника та за його рахунок.

Спеціальний спосіб захисту прав на засоби індивідуалізації передбачений ч. 2. ст. 20 Закону України «Про охорону прав на знаки для товарів i послуг»: якщо буде встановлено, що засоби індивідуалізації $€$ тотожними або схожими 3 іншими засобами індивідуалізації і така тотожність або схожість може призвести до введення в оману споживачі та (або) контрагентів, перевага надається тому засобу індивідуалізації, виключне право на яке виникло раніше у часі.

При цьому під частковою забороною на використання розуміється заборона щодо використання фрірмового найменування в певних видах діяльності; стосовно комерційного призначення - заборона на його використання в межах певної території та (або) в певних видах діяльності. Наведені положення формулюють єдиний підхід до вирішення актуального питання про співвідношення виключних прав на фрірмове найменування, комерційне позначення, торгова марка у випадку конкуренції цих прав. Загальним принципом $є$ перевага того із засобів індивідуалізації, виключне право на яке виникло раніше.

Відповідно до чинного законодавства тотожність або схожість до ступеня змішування засобів індивідуалізації частково виключається на стадії надання правової охорони: не можуть бути зареєстровані як торгові марки позначення у відносно однорідних товарів або які $€$ тотожніми чи подібними, права на які в Україні виникли у інших чи раніше дати пріоритету реєстрованого товарного знака.

Повна заборона на використання фірмового найменування веде до неможливості його використання i, отже, необхідності для юридичної особи зміни фрірмового найменування шляхом внесення відповідних змін до установчих документів. 
Отже, способами захисту, які спрямовані на припинення незаконного введення в господарський обіг контрафактних товарів або запобігання повторного їх введення слід вважати вилучення 3 цивільного обігу товарів, які були виготовлені, введені в господарський обіг з порушенням прав інших осіб; вилучення 3 цивільного обігу матеріалів та знарядь, за допомогою яких здійснювалося виготовлення товарів з порушенням прав інших суб'єктів господарювання. Названі способи вміщують в себе як відновлювальні (вилучення 3 обігу і знищення за рішенням суду об'єктів), так і припиняючі (вилучення 3 цивільного обігу матеріалів та знарядь, за допомогою яких здійснювалося виготовлення товарів 3 порушенням прав інших суб'єктів господарювання). Вказане підтверджує тезу про неможливість в окремих випадках відокремлення вказаних груп один від одного.

Висновки. Проведене дослідження дає підстави виділити спільні риси заходів відповідальності і заходів захисту: спрямовані за своїм впливом на правопорушника; мають на меті захист прав та інтересів потерпілого; можуть бути реалізовані як в добровільному порядку, так і примусовому; прямо закріплені в законодавстві; мають ретроспективний характер; можуть використовуватися як поодинці, так і у сукупності. Найбільш характерними для захисту в сорері прав на засоби індивідуалізації є такі припиняючі способи: припинення дій, які спрямовані на порушення виключного права або створюють загрозу такого порушення; вилучення з обігу і знищення за рішенням суду устаткування, пристроїв і матеріалів, використовуваних або призначених для вчинення порушення виключних прав; повна або часткова заборона на використання фірмового найменування або комерційного позначення; визнання такою, що не відповідає дійсності правової охорони товарному знаку; ліквідація юридичної особи на 
вимогу прокурора, припинення діяльності індивідуального підприємця в разі грубого порушення виключних прав.

\section{תimepamypa:}

1. Агамагомедова, С. А. (2011). Захист прав на зазначене походження товарів при їх транскордонному переміщенні. Патенти і ліцензії, 12, 24-25.

2. Андрощук, Г., \& Афрян, А. (2015). Конфлікт між торговельними марками та географічними значеннями: механізми вирішення. Теорія $i$ практика інтелектуальної власності, 1, 37-45.

3. Дмитришин В. С. (2008). Розпоряджання майновими правами інтелектуальної власності в Україні. Київ: Ін-т інтел. власн. і права.

4. Жаров, В. О. (2000). Інтелектуальна власність в Україні: правовіаспекти набуття, здійснення та захисту прав. Київ : ВидавничийДім “Ін Юре”.

5. Інтелектуальна власність у бізнесі: боротьба з тролями та бренд рейдерством. <http://vgolos.com.ua/articles/intelektualna vlasnist u bizn esi borotba z tr olyamy ta brendreyderstvom 176323.html >(2020, червень, 02).

6. Кодинец, А. А. (2010). Договора в сфрере интеллектуальной собственности: проблемы правового регулирования. Альманах цивилистики, 3, 225-252.

7. Крижна, В. М. (2008). Принцип справедливості, добросовісності та розумності і правові наслідки недійсності договорів у сорері інтелектуальної власності. Теорія i практика інтелектуальної власності, 6, 3-7.

8. Кузнецова, Н. С., Кохановська, О. В. (2011). Проблеми захисту прав на інтелектуальну власність в Україні. Право України, 3, 21-29. 
9. Мойсеєнко, І. П. (2015). Управління інтелектуальним потенціалом. Львів: Аверс.

10. Орлюк, О. (2015). Європейські орієнтири для національної сфери інтелектуальної власності. Сучасні проблеми порівняльного правознавства, 119-122.

11. Поліщук, В. Л. (2016). Роль нематеріальних активів у фрормуванні і розвитку конкурентноспроможності суб'єкта господарювання. Вісник Національного університету водного господарства та природокористування. Економічні науки, 2, 288-296.

12. Степаненко, С. (2017). Управління торговельними марками: боротьба з паразитизмом. Журнал європейської економіки, 13(1), 8093.

\section{References:}

1. Ahamahomedova, S. A. (2011). Zakhyst prav na zaznachene pokhodzhennia tovariv pry yikh transkordonnomu peremishchenni [Protection of rights to the specified origin of goods during their crossborder movement]. Patenty i litsenzii [Patents and licenses], no. 12, 24-25. [in Ukrainian].

2. Androshchuk, H., \& Afian, A. (2015). Konflikt mizh torhovelnymy markamy ta heohrafichnymy znachenniamy: mekhanizmy vyrishennia [Conflict between trademarks and geographical meanings: mechanisms for resolution]. Teoriia i praktyka intelektualnoi vlasnosti [Theory and practice of intellectual property], no. 1, 37-45. [in Ukrainian].

3. Dmytryshyn V. S. (2008). Rozporiadzhannia mainovymy pravamy intelektualnoi vlasnosti $v$ Ukraini [Disposal of intellectual property rights in Ukraine]. Kyiv: In-t intel. vlasn. i prava. [in Ukrainian].

4. Zharov, V. O. (2000). Intelektualna vlasnist v Ukraini: pravoviaspekty nabuttia, zdiisnennia ta zakhystu prav [Intellectual property in Ukraine: legal 
aspects of acquisition, exercise and protection of rights]. Kyiv : VydavnychyiDim "In Yure". [in Ukrainian].

5. Intelektualna vlasnist u biznesi: borotba $z$ troliamy ta brend reiderstvom [Intellectual property in business: fighting trolls and brand raiding]. Retrieved from

http://vgolos.com.ua/articles/intelektualna_vlasnist_u_biznesi_borotba_z_tr olyamy_ta_brendreyderstvom_176323.html [in Ukrainian]. (2020, June, 02).

6. Kodinec, A. A. (2010). Dogovora v sfere intellektual'noj sobstvennosti: problemy pravovogo regulirovanija [Agreements in the field of intellectual property: problems of legal regulation]. Al'manah civilistiki [Almanac of Civilization], no. 3, 225-252. [in Russian].

7. Kryzhna, V. M. (2008). Pryntsyp spravedlyvosti, dobrosovisnosti ta rozumnosti i pravovi naslidky nediisnosti dohovoriv u sferi intelektualnoi vlasnosti [The principle of fairness, good faith and reasonableness and the legal consequences of the invalidity of agreements in the field of intellectual property]. Teoriia i praktyka intelektualnoi vlasnosti [Theory and practice of intellectual property], no. 6, 3-7. [in Ukrainian].

8. Kuznetsova, N. S., Kokhanovska, O. V. (2011). Problemy zakhystu prav na intelektualnu vlasnist $v$ Ukraini [Problems of protection of intellectual property rights in Ukraine ]. Pravo Ukrainy [Law of Ukraine], no. 3, 21-29. [in Ukrainian].

9. Moiseienko, I. P. (2015). Upravlinnia intelektualnym potentsialom [Intellectual potential management] . Lviv: Avers. [in Ukrainian].

10. Orliuk, O. (2015). Yevropeiski oriientyry dlia natsionalnoi sfery intelektualnoi vlasnosti [European guidelines for the national sphere of intellectual property]. Suchasni problemy porivnialnoho pravoznavstva [Modern problems of comparative jurisprudence ], 119-122. [in Ukrainian].

11. Polishchuk, V. L. (2016). Rol nematerialnykh aktyviv u formuvanni i rozvytku konkurentnospromozhnosti subiekta hospodariuvannia [The role of 
intangible assets in the formation and development of the competitiveness of the entity]. Visnyk Natsionalnoho universytetu vodnoho hospodarstva ta pryrodokorystuvannia. Ekonomichni nauky [Bulletin of the National University of Water Management and Environmental Sciences. Economic sciences], no.2, 288-296. [in Ukrainian].

12. Stepanenko, S. (2017). Upravlinnia torhovelnymy markamy: borotba z parazytyzmom [Trademark management: combating parasitism]. Zhurnal yevropeiskoi ekonomika [Journal of European Economy], no.13(1), 80-93. [in Ukrainian].

Citation: A. Pekar (2020). SUSPENSIVE CIVIL REMEDIES FOR THE RIGHTS TO MEANS OF INDIVIDUALIZATION FROM UNFAIR COMPETITION: CIVIL-LAW RATIONALE. Innovative Solutions in Modern Science. 5(41). doi: 10.26886/2414-634X.5(41)2020.10

Copyright: A. Pekar (C). 2020. This is an openaccess article distributed under the terms of the Creative Commons Attribution License (CC BY). The use, distribution or reproduction in other forums is permitted, provided the original author(s) or licensor are credited and that the original publication in this journal is cited, in accordance with accepted academic practice. No use, distribution or reproduction is permitted which does not comply with these terms. 